\title{
Surgical Treatment of a Saggital Intraarticular Femoral Head Fracture with Coxofemoral Dislocation in Two Mature Dogs
}

\author{
A. NEČAS, M. DVOŘÁK \\ Department of Surgery and Orthopaedics, Small Animal Clinic, Faculty of Veterinary Medicine, \\ University of Veterinary and Pharmaceutical Sciences, Brno, Czech Republic \\ Received February 14, 2003 \\ Accepted May 26, 2003
}

\begin{abstract}
Nečas, A., M. Dvořák: Surgical Treatment of a Saggital Intraarticular Femoral Head Fracture with Coxofemoral Dislocation in Two Mature Dogs. Acta Vet. Brno 2003, 72: 261-265.

The surgical treatment of two cases of craniodorsal hip luxation with an associated saggital intraarticular fracture through the femoral head is described. The method of repair consisted of an open reduction via a craniolateral approach to the hip joint and internal fixation of the fracture with a lag screw and a Kirschner wire. One case was complicated by an ipsilateral complex femoral fracture and contralateral luxation of the hip joint with avulsion of a small bone fragment from the femoral head. Both dogs were clinically sound ten to twelve months after surgery.
\end{abstract}

Hip joint, luxation, trauma, fracture

Two types of intraarticular femoral head fractures are seen associated with coxofemoral dislocation in mature dogs. Each type presents a challenge to veterinary surgeon to achieve a satisfactory outcome. The more common type involves avulsion of a small portion of the femoral head, which is normally attached to the round ligament. The fragment is too small to be adequately stabilized and its presence may result in failure of attempts at treatment of the dislocated hip by closed reduction. Excision of the fragment is indicated at the time of open reduction of the hip.

The second, less common type, is when dislocation of the hip is associated with a much larger saggital fracture through the femoral head. Only a small number of papers have been published, which discuss the methods of treating this more complex injury (Vernon and Olmstead 1983; L'Eplattenier and Montavon 1997). If the fragment is larger than one-quarter of the femoral head, then the opportunity exists to reduce and stabilize the fracture with lag screws or with a combination of a lag screw and a small pin. Important factors to consider helping to ensure a successful outcome include an atraumatic surgical approach, with due regard to preservation of the blood supply to the fragments and accurate reduction with rigid fragment fixation. The purpose of this paper is to report on the outcome of further two cases.

Craniodorsal hip luxation with an associated saggital fracture through the femoral head usually occurs in mature dogs because in the immature dog the proximal femoral growthplate is the weak link. The two common causes of craniodorsal hip luxation are either a car accident or a fall from height (Wadsworth 1993). If the dog is hit by a car from behind, the animal starts to fall toward the hip to be luxated and the rear leg on this side moves into adduction. It is theorised that the centre of gravity of the animal moves lateral to the hip joint and as the hip moves toward the ground, the long lever arm of the adducted femur femoral shaft draws the femoral head out of the acetabulum as far as the joint capsule will allow. When the greater trochanter strikes the ground, the force is transmitted through the femoral neck to the femoral head, driving the head over the dorsal rim shearing the joint capsule and 
the round ligament. Craniodorsal luxation can also occur when the hind quarters are driven ventrally towards the ground with the leg extended and the foot weight bearing. The pelvis is forced ventrally and the knee and hip flex. At some stage, before the pelvis hits the ground, the knee makes contact with the ground and as the pelvis moves ventrally the hip begins to rotate externally. If the force is of sufficient magnitude the teres ligament and the joint capsule rupture and the tension in the gluteal muscles results in luxation of the femoral head in a craniodorsal direction (Wadsw orth 1993).

Although the hip is a typical ball-and-socket joint (Evans 1993), it is not well protected against luxation. There are no collateral ligaments and the major stabilising structures of the joint are the joint capsule, the round ligament and the muscles attached to the proximal end of the femur, plus the hydrostatic force exerted by the viscosity of the synovial fluid. In individuals affected by hip dysplasia, the articular and periarticular structures may become stretched and that predisposes the joint to luxation (B ojrab 1993). The blood supply to the femoral head and neck arises from the lateral circumflex femoral artery, the medial circumflex femoral artery, and to a limited extent from a branch of the caudal gluteal artery (Kaderly et al. 1982). The network from these vessels within the retinaculum penetrates the joint capsule. Clinical observations indicate that, when the femoral head fracture is intracapsular, the ventral joint capsule strips from the femoral neck, leaving intact the retinacular blood supply from the medial circumflex femoral artery to the femoral head (Brinker et al. 1998).

Craniodorsal hip luxation with an associated saggital fracture through the femoral head should be treated by open reduction. Closed reduction is not indicated because of the risk of reluxation of the femoral head and the likelihood of developing degenerative joint disease secondary to the damage caused to the articular cartilage and the irritation from the intraarticular fragment.

\section{Materials and Methods}

Two cases of craniodorsal hip luxation with an intraarticular femoral head avulsion fracture were operated on at the Department of Surgery and Orthopaedics, University of Veterinary and Pharmaceutical Sciences in Brno between 1989 and 1997. In each case the fragment of the femoral head was equal to one-quarter the femoral head or more.

The first patient was a Bernese Mountain Dog, aged 4 years and weighing $40 \mathrm{~kg}$, diagnosed with a craniodorsal luxation of the left hip joint with an associated fragment in the size of approximately $1 / 3$ of the femoral head (Plate IX, Fig. 1). The fracture was a sequel of a jump from height. The patient was operated on 24 hours following the trauma.

The second case was a Schnauzer dog aged 1.5 years and weighing $16 \mathrm{~kg}$, that had been hit by a car and sustained multiple injuries of soft and hard tissues of both pelvic limbs. These injuries comprised of a craniodorsal luxation of the right hip joint and an associated femoral head fracture, a complex diaphyseal fractures of the right femur and a craniodorsal luxation of the left hip joint with an associated small avulsion fracture of the femoral head (Fig. 2). Surgery was delayed for 48 hours so that the patient could be stabilized.

The surgical technique used to repair the fracture of the femoral head was the same for both patients.

Following the induction of general anaesthesia the affected limb was prepared for surgery from the midline to the hock joint. The patient was positioned in lateral recumbency with the injured leg up. The limb was draped to allow its free manipulation. A craniolateral approach to the hip joint was used which included a partial tenotomy of $\mathrm{m}$. gluteus, profundus and a partial myotomy of $\mathrm{m}$. vastus lateralis (Piermattei and Greeley 1979). The round ligament was damaged in both the cases and the remnants of the ligament were debrided and the joint cavity flushed with lactated Ringer's solution. The preoperative plan was to repair the fracture with a lag screw. Prior to the reduction of the fracture of the femoral head, the gliding hole was created in the main fragment. The fracture of the femoral head was then anatomically reduced and held it in position by sharp reduction forceps. The threaded hole in the femoral head fragment was drilled using a drill guide to insure accurate centering. The hole was measured and tapped so that a $2.7 \mathrm{~mm}$ cortical lag screw could be inserted. In order to achieve additional rotational stability a Kirschner wire was inserted parallel to the lag screw. The joint capsule was closed with a cruciate suture pattern using non-absorbable monofilament synthetic material (Prolene, USP 2-0). The tendinous parts of $\mathrm{m}$. gluteus profundus and $\mathrm{m}$. vastus lateralis were closed with a Kessler's locking-loop suture pattern using Prolene (USP 2-0). The remaining tissues were closed layer by layer in a routine way. 
In the Schnauzer, in addition to repair of the femoral head fracture in the right hip, the contralateral luxation of the femoral head was treated by open reduction and excision of the small bone fragment together with the remains of the round ligament. The joint capsule was sutured with a cruciate suture pattern by Prolene (2-0). The fracture of the right femur was treated using two $2.7-\mathrm{mm}$ lag cortical screws and a $2.7-\mathrm{mm}$ DCP plate with neutralization function.

For the first 14 days following the procedure the limbs were supported using Ehmer sling. The owner was instructed to reduce the activity of the dog (by leash walking) for another 4-week period and perform physiotherapy (passive flexion and extension, swimming).

\section{Results}

In both cases the saggital intraarticular femoral head fracture with coxofemoral dislocation was treated by open reduction via a craniolateral approach to the hip joint and internal fixation of the fracture with a lag screw and anti-rotational Kirschner wire. Anatomical reduction of the fracture with reposition of luxated femoral head was achieved in both cases (Plate IX, Figs 3, 4; Plate X, Fig 5). There were no complications with wound healing. The first dog showed no lameness 6 weeks after surgery and was allowed to gradually return to a normal physical activity 2 months after surgery. In the second patient with the more complex injuries, there was no evidence of lameness 5 weeks after surgery in the left hind leg and full function was restored to the right hind leg 8 weeks after surgery.

The femoral head fractures were clinically and radiographically healed 8 weeks after surgery. The femoral heads were in a normal position relative to acetabulum and there were no signs of degenerative joint disease (Plate X, Figs 6 and 7). The complex femoral fracture in Schnauzer was completely healed 12 weeks after surgery. There was no evidence of degenerative joint disease in the left hip treated by open reduction and debridement of the intraarticular debris. All the implants were in place and were not removed. On the postoperative follow-up examinations ten to twelve months after surgery, both dogs showed no sign of lameness, the hip joints remained stable with only slight discomfort on maximal extension, external rotation and abduction of the hip.

\section{Discussion}

If we adhere to principles of anatomical reduction and rigid fixation when operating on fresh fractures of the femoral head, the risk of avascular necrosis of the head and neck is low. Some narrowing of the femoral neck is due to quick revascularisation, resorption and remodelling of the bone (Olmstead 1995; Slatter 1993). The selection of the operative approach and the time elapsing from the origin of the injury, however, seem not to influence the narrowing of the femoral neck.

It is recommended not to attempt closed reduction prior to surgery in cases with saggital fractures to avoid further damage to the articular cartilage which may lead to subsequent osteoarthritic changes (Bojrab 1990; Brinker et al. 1990; Whittick 1990).

Two different surgical approaches to the hip joint have been used in conjunction with femoral head fracture fixation. The first is the craniolateral approach (Vernon and Olmstead 1983), and the second is ventral approach to the hip joint ( $\mathrm{L}^{\prime}$ Eplattenier and Montavon 1997). Both approaches have advantages and disadvantages with respect to the surgeon's ability to reduce and stabilize the fracture and to achieve a stable reduction of the dislocation. The craniolateral approach to the hip joint including a partial tenotomy of $\mathrm{m}$. gluteus profundus and a partial myotomy of $\mathrm{m}$. vastus lateralis (Piermattei and Greeley 1979) was chosen in our two clinical cases. Using the craniolateral approach and fixation with a lag screw and antirotational Kirschner wire for the fracture fixation, the implants do not damage articular cartilage of the femoral head. This is in contrast to the ventral approach recommended by L'Eplattenier and Montavon (1997). In this approach fixation involves countersinking the implants under the joint surface of the head. They argue that the 
damage to the hyaline cartilage caused by drilling of the screw holes through the articular surface and the presence of the countersunk implants is well tolerated as the holes fill with fibro-cartilage. We prefer to leave the hyaline articular cartilage undamaged as we feel that the presence of the fibro-cartilage and the possibility of an irregular joint surface may lead to degenerative joint disease (DJD).

Other advantages of the craniolateral approach to the hip are familiarity with the approach (Kuzma et al. 1989; Miller and Anderson 1993; Montavon et al. 1998) and the opportunity to repair the craniolateral part of joint capsule, which is damaged with craniodorsal hip luxation. The joint capsule reconstruction contributes to postoperative joint stability. The round ligament is always damaged with dislocation of the hip. However, with the complication of a saggital fracture some of the round ligament may be left intact and attached to the fragment. In our experience it is better to transect the round ligament in order to achieve anatomical reposition of the fracture fragments. We believe that transection of the round ligament to allow accurate reduction of the fracture is more important than trying to preserve the ligament and risk the possibility of an unfavorable fracture reduction.

In practice, we can see many traumatic craniodorsal coxofemoral luxations, which are treated successfully by either closed or open reduction, that are stable and without excessive progression of DJD. The prognosis concerning hip joint stability and the development of DJD also depends on the possibility of dysplasia of the hip joint. In our two patients, there were not obvious progression of DJD on the postoperative radiographs 8 weeks and 12 weeks after surgery, respectively.

\section{Conclusion}

The successful treatment of two cases of traumatic coxofemoral dislocation with an associated saggital femoral head fracture is described. Open reduction via a craniolateral approach to the hip joint and internal fixation of the fracture with a lag screw and antirotational Kirschner wire was the method employed.

\section{Fixace fraktury hlavice femuru při kraniodorzální luxaci kyčelního kloubu u dvou psů}

V článku je popsáno chirurgické řešení klinických př́ípadů kraniodorzální luxace kyčelního kloubu s frakturou hlavice femuru u dvou psů. Spočívá v repozici kloubu pomocí kraniolaterálního př́stupu a fixaci fragmentu hlavice femuru tažným šroubem a Kirschnerovým drátem. V jednom případě bylo toto trauma komplikováno ipsilaterální komplexní zlomeninou stehenní kosti a luxací druhostranného kyčelního kloubu s avulzní frakturou hlavice femuru s drobným fragmentem.

\section{Acknowledgements}

This work was supported by the Ministry of Education, Youth and Sports of the Czech Republic (Research Project No. 161700002).

\section{References}

BOJRAB, MJ 1990: Current Techniques in Small Animal Surgery. 3rd ed., Philadelphia, Lea \& Febiger, pp. 682685

BOJRAB, MJ 1993: Disease Mechanisms in Small Animal Surgery. Philadelphia, Lea \& Febiger, pp. 1054-1055

BRINKER, WO, PIERMATTEI, DL, FLO, GL 1990: Handbook of Small Animal Orthopaedics and Fracture Treatment. 3rd ed., Philadelphia, W. B. Saunders, pp. 486-488

BRINKER, WO, OLMSTEAD, ML, SUMNER-SMITH, G, PRIEUR, WD 1998: Manual of Internal Fixation in Small Animals. 2nd ed., Springer, pp. 155-158

EVANS, HE 1993: Miller's Anatomy of the Dog. 3rd ed. Philadelphia, W. B. Saunders

L'EPLATTENIER, HF, MONTAVON, PM 1997: Avulsion Fractures of the Femoral Head: Internal Fixation Using a Ventral Approach to the Hip Joint. Vet Comp Ort Traum, 1: 23-26

KADERLY, RE, ANDERSON, WD, ANDERSON, BG 1982: Extraosseous Vascular Supply to the Mature Dog's 
Coxofemoral Joint. Am J Vet Res 43: 1208-1214.

KUZMA, A, SUMNER-SMITH, G, MILLER, C, MC LAUGHLIN, R 1989: A Technique for Repair of Femoral Capital Epiphyseal Fractures in the Dog. J Small Anim Pract 30: 444-448

MILLER, A, ANDERSON, TJ 1993: Complication of Articular Lag Screw Fixation of Femoral Capital Epiphyseal Separations. J Small Anim Pract 34: 9-12

MONTAVON, PM, POHLER, OEM, OLMSTEAD, ML, WENDELBURG, KL 1998: The Mini Instrument and Implant Set and Its Clinical Application. Vet Comp Ort Traum 1: 44-51

OLMSTEAD, ML 1995: Small Animal Orthopaedics. Mosby, pp. 228-230

PIERMATTEI, DL, GREELEY, RG 1979: An Atlas of Surgical Approaches to the Bones of the Dog and Cat. 2nd ed., Philadelphia, W. B. Saunders, pp. 132-133

SLATTER, DH 1993: Textbook of Small Animal Surgery. Vol. 2. Philadelphia, W. B. Saunders, pp. 1805-1808

VERNON, FF, OLMSTEAD, ML 1983: Femoral Head Fractures Resulting in Epiphyseal Fragmentation: Results of Repair in 5 Dogs. Vet Surg 12: 123-125

WHITTICK, WG 1990: Canine Orthopaedics, Lea \& Febiger, 2nd ed., pp. 417-430 

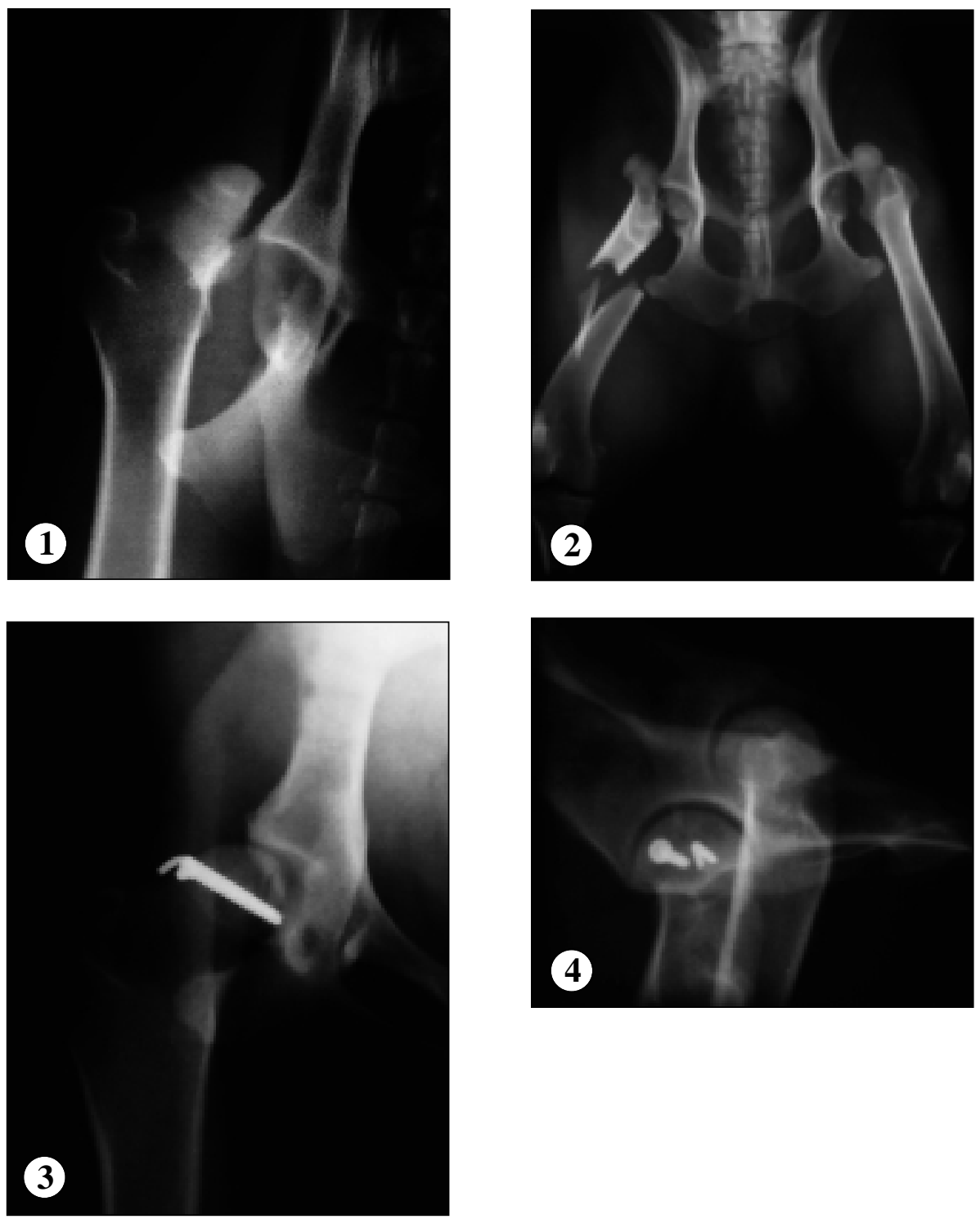

Fig. 1: Radiograph of coxofemoral dislocation with saggital femoral head fracture in a four-year- old Bernese Mountain Dog.

Fig. 2: Craniodorsal luxation of the right hip joint and an associated femoral head fracture in a 1.5 -year- old Schnauzer dog. The condition was complicated by complex right diaphyseal femoral fracture and a craniodorsal luxation of the left hip joint with an associated small avulsion fracture of the femoral head.

Fig. 3: Post-operative radiograph (ventrodorsal view) of the hip joint in the same dog as in Fig. 1. Anatomical reduction of the fracture with reposition of luxated femoral head.

Fig. 4: Post-operative radiograph showing anatomical reduction of the hip joint in laterolateral view in the same dog as in Fig. 1. 
Plate X
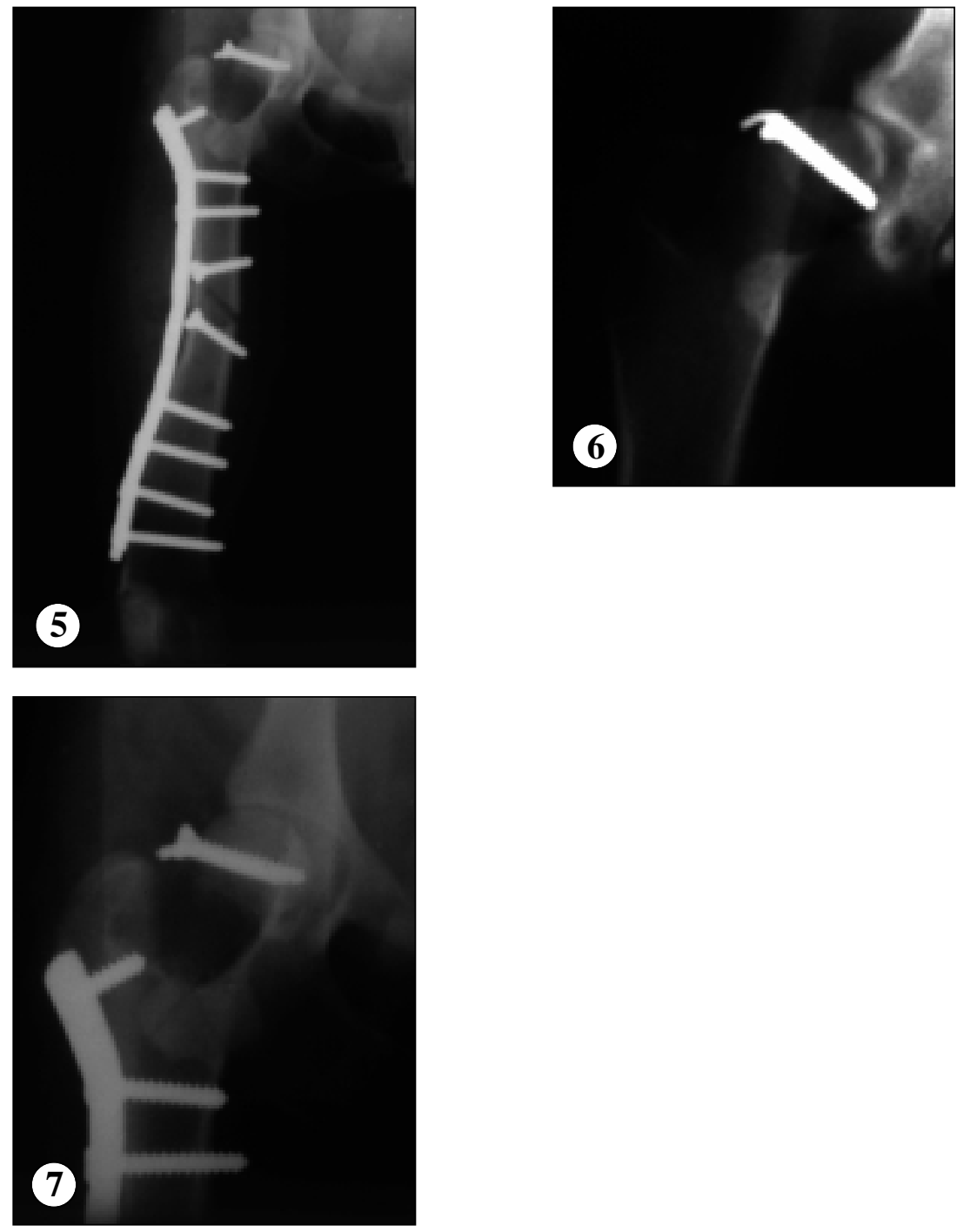

Fig. 5: In addition to repair of the femoral head fracture the diaphyseal femoral fracture in the Schnauzer (same dog as in Fig. 2) was treated using two 2.7-mm lag cortical screws and a 2.7-mm DCP plate with neutralization function: post-operative radiograph.

Fig. 6: Follow-up radiograph 8 weeks after surgery in the same dog as in Fig. 1. No signs of degenerative joint disease were detected.

Fig. 7: The femoral head fracture in the Schnauzer (same dog as in Fig. 1) was radiographically healed and there were no DJD changes 8 weeks after surgery. 